\title{
IMMUNOSUPPRESSION - POSTPARTUM DISEASES OF DAIRY COWS
}

\author{
M. Joksimović Todorović, V. Davidović \\ University of Belgrade, Faculty of Agriculture, Nemanjina 6, 11080, Belgrade-Zemun, Republic of \\ Serbia \\ Corresponding author: miratodo@agrif.bg.ac.rs \\ Review paper
}

Abstract: Periparturient period in dairy cows is accompanied by numerous physiological, metabolic and nutritive changes. The way in which they occur and develop have a great influence on lactation performances, subclinical and clinical postparturient diseases and reproductive disorders, thus affecting the profitability as well. During periparturient period dairy cows may subject to the immune system function disorders. This immunosuppression leads to increased number of severe cases of infections (mastitis, metritis, retained placenta and other health disorders). The cause of periparturient immunosuppression is unknown, although it is a subject of numerous studies which suggest that immune disfunction may be provoked by both metabolic and endocrine factors. Numerous authors suggest that negative energy balance, non-esterified fatty acids (NEFA), ketone bodies and hypocalcaemia play a significant role in the development of immunosuppression. It is well known that glucocorticoids exert an immunosuppressive action. The changes in the levels of estradiol and progesterone may have either a direct or indirect influence on immune defence. However, their effect on the development of this immunofunction is not long, since the changes in their concentrations are short-lasting. Some nutrients are involved in the function of immune cells thus minimizing the inflammatory damages, due to more efficient immune response. Numerous tissue damages during the infection are possible, as a consequence of oxidative stress - reaction of unstable oxidised molecules with tissue lipids, proteins and DNA. A great number of antioxidants are important for animal health, however, optimal concentrations and forms of these supplements for maximizing the immune function and tissue protection are still unknown.

Key words: dairy cows, immunosuppression, oxidative stress, antioxidants-application, post-parturient diseases. 


\section{Introduction}

During periparturient period in dairy cows, three weeks prior to and three weeks after calving the reduction in immune functions is perceived. The occurred immune disfunction results in the increased number of infections and their severity in this period (Waldron, 2010). The cause of this immune disfunction is unknown, however numerous factors may be involved. Metabolic disorders and change in the level of some hormones (glucocorticoids, estradiol and progesterone) most likely affect the decrease in immune function (Waldron and Revelo, 2008). Glucocorticoids, are known as immunosuppressors, and since their level increases in the calving period they are partially responsible for periparturient immunosuppression. The changes in the level of estradiol and progesterone at calving may have both direct and indirect effect on immune response (Weber et al., 2001). The changes in the level in any of these hormones do not match with an entire period of immunosuppression, suggesting that some other factors may also be responsible for its incidence.

The infections of mammary gland (mastitis) and uterus (metritis) are common in dairy cows during periparturient period. Other health disorders that occur in this period are milk fever and ketosis. Although the etiologies of infections and metabolic disorders are different, there is a significant relationship between their activities. In cows infected by milk fever, clinical mastitis is observed five times more in comparison with the cows that have no such health problem (Curtis et al., 1985).

During inflammatory diseases, immune cells produce reactive oxygen species (ROS) (Sordillo and Aitken, 2009). Leukocytes use these toxic components as a part of arsenal when destroying the pathogens. However, those same molecules can also cause the damage of mammary tissue. Although very efficient against pathogenes an unfavourable feature of these oxidants is non-selectivity when there is a case of the "damaging" of cells, thus being frequent and significant damage of some tissues. This happens when there is a disbalance between the increased production of ROS and available antioxidative defence, necessary to reduce ROS accumulated during periparturient period. In this period the cows are exposed to strong oxidative stress. Previous studies indicated the importance of oxidative stress in etilogy of diseases in dairy cows. The studies made in the last ten years support the concept that oxidative stress is a significant factor in the development of disfunction of animal immunity and inflammatory response and that it may increase the sensitivity of individuals to different health problems, particularly during the transitional period (Sordillo, 2005; Wilde, 2006).

Selenium and E vitamin are the most studied antioxidants in relation to the health status in young cows, since their addition into the rations during 
periparturient period can reduce the severity and duration of disease occuring in this period.

Metabolic and nutritional challenges of periparturient dairy cows

The research in the field of both human and veterinary medicine has indicated a close relation between nutrition, inflammation and sensitivity to ailments (Calder, 2008; Wood et al., 2009). Certain physiological changes occuring in cows during transitional period may affect the nutritive status and contribute to the increase in sensitivity to some diseases. In this period the needs for energy are elevated, provoked by the beginning of lactation and reduced intake of dry matter, what leads the individual into the state of negative energy balance. Approximately $85 \%$ glucose goes directly into the mammary gland for the synthesis and secretion of milk. Moreover, the need for aminoacids increases, because the liver utilizes them as gluconeogenetic substrate, what results in mobilizartion of protein from skeleton muscles. The consequence of negative energy balance is the mobilisation of fats from body depos and departure of unsaturated fatty acids into the blood. Continued lipolysis results in transformation of NEFA into triglycerides, and their accumulation in liver may result in the disease called "fatty" liver. In recent years the importance of NEFA for inflammatory response has been pointed out, although the major mechanisms of their effects are still the subject of research (Sordillo et al., 2009). It is thought that there are several mechanisms by which NEFA can regulate inflammatory response. Fatty acids may be built into membrane lipids and affect some important cell functions (Martins de lima et al., 2007).

\section{Effects of metabolic challenges on immunocompetence}

Negative energy balance in dairy cows may affect the creation of immunosuppression (Waldron, 2010). However, in cattle, experimentaly induced energy balance in individuals has a small effect on the creation of adhesive molecules on the surface of leukocytes (Perkins et al., 2001). Some studies suggest that nutritive balance and metabolic disorders have no strong influence on the creation of immunosuppression but that some other changes are likely to be responsible for this immune disfunction. In contrast to these opinions, some researchers suggest that certain components are connected with negative energy balance concluding that only hypoglycaemia has no influence on the incidence of immunosuppression (Nonnecke et al., 1992), while hyperketonemia has a multifold negative effect on immune functions (Suriyasathaporn et al., 2000). Ketosis may increase the danger of the incident of mastitis in cows with immunosuppression, because immune cells suffer negative effects and in this way the defence 
mechanisms of the mamary gland are weakened. In cows having ketosis blastogenesis of lymphocytes is in supremacy, the activity of respiratory burst is reduced along with neutrophils chemotaxic ability, and also, the titre of $\gamma$ interferon and TNF- $\alpha$ in aorta endotheliumel cells in cattle are reduced as well. Certain studies suggest that calcium metabolism may affect the immunecompetence. Significant quantities of calcium are necessary for the synthesis of milk and start of lactation, therefore the hypocalcemia is frequent in dairy cows. Calcium is important also for intracellular metabolism and a signal ion for numerous cells including leukocytes so that the low level of calcium in calving period may contribute to the incidence of immunosuppression. Kimura et al. (2006) said that the low level of calcium content in mononucleus leukocytes may lead to immunosuppression. The authors state that the level of intracellular calcium is a more sensitive indicator of metabolic stress than the level of calcium in blood.

\section{Oxidative stress}

Oxidative stress is also an important factor which provokes disfunction of inflammatory response in metabolic stress in cows during periparturient period (Sordillo and Aitken, 2009). It happens when reactive oxygen species (ROS) are present in higher concentration, while enzyme and non-enzyme antioxidants are deficient. The increased generating of ROS during periparturient period results in spending important antioxidative defence mechanisms (Gitto et al., 2002). Reactive oxygen species are primarily formed as the end products of mitochondrial respiratory chain or by the activation of NADPH oxidase (Sordillo and Aitken, 2009). The most important ROS forms are: superoxide anion $\left(\mathrm{O}_{2}{ }^{-}\right)$, hydrogen peroxide $\left(\mathrm{H}_{2} \mathrm{O}_{2}\right)$ and the most reactive hydroxil radical $(\mathrm{OH})$. Great quantities of superoxide anions and hydrogen peroxide are produced during oxidative burst, when the phagocyte cells are stimulated by NADPH oxidase for destroying pathogenic agents (Valko et al., 2007). Hydroxil radical breaks DNA chains, modifies purine and pirimidin bases and molecules of desoxiribosis. DNA oxidative damages lead to transcription changes and permanent damages in humans, however, such an influence in dairy cows is unknown. Oxidative stress in dairy cows during transitional period is connected with a significant increase of lipid peroxidation (Castillo et al., 2006).

Physiological stress is associated with very rapid differentiating of secretory parenchyma, intensive growth of mammary gland, onset of abundant synthesis and secretion of milk, high energy requirements and the need for oxygen (Gitto et al., 2002). Increased needs for oxygen lead to the conditions which are the basis for ROS generating. For that reason the oxygen which is essential for aerobic organisms can be also called "oxygen paradox". Production of free radicals is 
controlled by antioxidative defense system. Antioxidants can delay, prevent or remove oxidatively damaged target molecules (Halliwell and Gutteridege, 2007). Antioxidative defence system can be divided into enzyme (superoxide dismutasis (SOD), gluthatione peroxidase (GSH-Px) and catalase and non-enzyme mechanisms (vitamin E and selenium) (Sharma et al., 2011). Abundant production of free radicals and ROS weakens the defence, leads to damage of macro molecules and disorder of metabolic processes (Trevisan et al., 2001; Joksimović Todorović and Davidović, 2007). When ROS is produced faster than it can be neutralised by antioxidants, the result thereof is oxidative stress.

\section{Antioxidants - application}

It is thought that $\mathrm{Se}$ and vitamin $\mathrm{E}$ are the key ingredients of food performing oxidative protection. Vitamin $\mathrm{E}$ is an integral component of all lipid membranes, it acts inside them and neutralises free radicals, as well as those produced by lipid peroxidation. It represents the first line of cellular defence against free radicals.

Selenium performs its biological role in organism through enzyme gluthatione peroxidase (GSH-Px). The activity of this enzyme depends on the level of selenium in food, what can be used as a reliable indicator of selenium biological available (Mihailović et al., 1991). However, at certain concentrations of selenium, the activity of GSH-Px reaches plateau, so that further increase of the selenium level results in no increase of the activity of this enzyme. High selenium levels added into food ( $>5 \mathrm{mg} / \mathrm{kg}$ ) lead to no linear increase of the activity of this selenoenzyme. In the first days the selenium activity increases in animal blood plasma, but only 10 days later a significant fall occurs therein (Joksimović Todorović and Jokić, 2005; Joksimović Todorović et al., 2005).

In the nutrition of domestic animals the organic selenium in the form of selenomethionine (present in plants in different concentrations) and non-organic selenium in the form of sodium selenite or selenate are used. The difference between these two forms of selenium is in metabolic path and efficiency of action. High levels of selenite are more toxic than the same levels of organic selenium (Mihailović et al., 1996a,b; Mihailović et al., 1997; Todorović et al., 1999). It can generally be said that adequate selenium levels in food are crucial factors in ensuring animal good health and their high productivity (Jokić et al., 2005; Joksimović Todorović et al., 2006).

Antioxidative status may be one of the factors which influences the reproductive functions in dairy cows. Selenium and vitamin E reduce the incidence of postparturient ailments in dairy cows - retained placenta, metritis and ovarian cysts and increase the level of conceptions. Neutrophile granulocytes in dairy cows blood contain very low catalase. Reduced function of neutrophile 
granulocytes is connected with high levels of superoxide $\left(\mathrm{O}^{-}\right)$. Inadequate protection from ROS leads to reduction in the function of neutrophile granulocytes, what causes frequent diseases. Primary function of $\mathrm{Se}$ is to secure the immunological defence and to augment the migration of neutrophile granulocytes towards inflammatory region, where it will phagocyte and destroy present bacteria. Selenium deficiency leads to reduction in both number and disorder of functions of all cells of immune system. There are some disorders observed in maturing of lymphocytes, and in the function of mature forms as well. The activity of $\mathrm{T}$ lymphocytes and NK cells (killer cells) is decreased, as well as the synthesis of some antibodies, particularly IgM class. Selenium intensifies the response to antigenic stimulation, and the activity of NK cells.

\section{Mastitis}

Dairy cows are exposed to numerous genetic, physiological and external factors, which can endanger the immunity and increase the frequency of mastitis (Sordillo, 2011). Selection in the direction of maximum milk production enhances metabolic stress provoked by increased synthesis and secretion of milk and reduces the resistance to mastitis.

Mammary gland is protected by defence mechanisms - natural and acquired immunity. Natural immunity is dominant during various infections. It is being activated rapidly on the site of infection by numerous stimulants, but it is not enlarged by re-exposure to that same cause. If natural mechanism of defence functions adequately, many pathogenes can be easily removed in a short period. If pathogenes are not completely eliminated, then a specific immunological system is activated (Sordillo and Streicher, 2002).

The use of antioxidants in dairy cows reduces the duration and intensity of diseases. Accurate mechanisms of improving the health of mammary gland are not fully known, and they are brought into connection with their antioxidative functions, including cellular signals and reduction of oxidative damages of mammary tissue. Antioxidants in dairy cows enhance the resistance to mastitis, ensure phagocyte capacity of neutrophiles, increasing the hemotaxis on the place of infection (Spears and Weiss, 2008).

\section{Retained placenta}

Retained placenta is the most frequent disease in dairy cows perceived in $4-18 \%$ calved individuals. Rejection of placenta occurs in the period from 2-8 hours after calving. Retention of placenta longer than 12 hours represents the state of illness. Fetal placenta is regarded as an "alien tissue" and is being rejected after parturition. Numerous factors including mechanical, nutritional, management and 
infectious causative agents may affect the incidence of this disease. Mechanical causal factors comprise difficult delivery, caesarean section, uterus torsion, abortion, still born calf, emphysema fetus and twinning. Nutritional causes comprise deficit of energy, protein, selenium, iodine, vitamins $\mathrm{A}$ and $\mathrm{E}$ and calcium, during pregnancy. Management causes involve stress, external factors and overweight. Incidence of retained placenta is frequent (about $50 \%$ animals) in relation to zoonoses such as brucellosis, salmonellosis, leptospirosis and listeriosis (Gunay et al., 2011). Certain studies show that the retained placenta is one of the major causes of endometritis in cows (Han and Kim, 2005). Retained placenta is the cause of reduced fertility, and therefore reduced fertility rate, more difficult conception and can prolong calving interval (Bella and Roberts, 2007). Selenium and vitamin $\mathrm{E}$ promote the function of neutrophiles, affect their migration and hemotaxic activity. These nutrients elevate the number of neutrophiles in placenta and affect the weakening of links between fetomaternal joint (cotyledon and caruncle). Elevated concentration of cortisol is a response to stress and inflammation of pregnant uterus. Cortisol reduces the function of thermophiles or hinders absolutely their activity and therefore provokes the incidence of this disease.

\section{Abomasum dislocation}

Abomasum dislocation in high productive diary cows affect the physiology of abomasum. In $95 \%$ cases abomasum moves either to left or right thoracoabdominal position. Enlarged abomasum, can also change the position in cranial direction. In that case, dislocated abomasum is placed between the reticulum and diaphragm (Zadnik, 2003). The studies pointed to the fact that three days before the incidence of clinical symptoms the production of milk significantly reduces. In case of left dislocation of abomasum milk production is reduced by $16.6 \%$, while in case of right $43.5 \%$. Animals are less active, and their body mass reduces by 15.9 , ie. $22.9 \%$. During the manifestation of clinical symptoms the milk production is reduced by $60.5 \%$ (Antanaitis et al., 2009).

This ailment is provoked by stress, nutritional diseases and metabolic defects. High productive dairy cows fed large quantities of cereals may have an abomasum atony. Factors which may lead to atony include metabolic diseases (hypocalcemia and ketosis), postparturient diseases (mastitis, metritis, retained placenta and milk fever). In individuals with abomasum dislocation, possible complications in ketosis and metritis are increased. In animals with left abomasum dislocation the movements of rumen are reduced to up to two to a half movement in a minute, while in some cases the rumen is atoned. Gas production is increased due to prolonged fermentation in abomasum (mostly methane and carbon dioxide are being accumulated). Defecation is considerably reduced while feces is usually small. The incidence of leukocytosis and neutrophilia in abomasum left dislocation 
is regarded as an immunological response to endotoxemia provoked by this disease (El-Attar et al., 2007). It is thought that abomasum dislocation is connected with hemoconcentration, electrolytes imbalance, liver disorders and hypocalcemia. Therefore it is necessary, in the first 4 weeks after parturition, to maintain energy balance, electrolytes balance and normocalcemia by properly planned diet (Mokhber Dezfouli et al., 2011). The first lactation is highly risky what can be a consequence of poor social and nutritive adaptation.

\section{Conclusion}

Periparturition diseases in dairy cows are a source of constant concern for producers, nutritionists and vets. The researchers generally think that the immunosupression is the cause of incidence of these diseases, although there are some different viewpoints on what can cause immune disfunction. However, they all agree that rations supplemented by certain nutrients prevents the development of postparturient diseases. A proper nutritive profile ensures animal metabolic soundness and it seems to be the best strategy in preserving and improving the immune functions. Moreover, hygiene and minimizing the stress are the most important in prevention of diseases in dairy cows.

\section{Acknowledgment}

This work was financed by the Ministry of Education, Science and Technological Development, Republic of Serbia, project TR 31086: Optimisation of technological procedure and zootechnical resources on farms with the aim of improving the sustainability of milk production.

\section{Imunosupresija - postpartalna oboljenja mlečnih krava}

\section{Joksimović Todorović, V. Davidović}

\section{Rezime}

Peripartalni period kod mlečnih krava prate brojne fiziološke, metaboličke i nutritivne promene. Način na koji se one dešavaju i kako se odvijaju imaju veliki uticaj na laktacione performanse, subklinička i klinička postpartalna oboljenja, reproduktivne poremećaje, a sami tim utiču i na rentabilnost.

U toku peripartalnog perioda mlečne krave podležu poremećaju funkcije imunskog sistema. Ova imunosupresija dovodi do povećanja broja i ozbiljnosti infekcija (mastitis, metritis, zadržavanje posteljice i drugi zdravstveni poremećaji). 
Uzrok peripartalne imunosupresije nije poznat, ali je predmet brojnih istraživanja koja sugerišu da je imunska disfunkcija uzrokovana metaboličkim i endokrinim faktorima. Brojni autori navode da negativni energetski bilans, nezasićene masne kiseline (NEFA), ketonska tela i hipokalcemija, imaju značajnu ulogu u razvoju imunosupresije. Poznato je da glukokorikosteroidi imaju imunosupresivno dejstvo. Promene nivoa estradiola i progesterona takođe mogu imati direktan i indirektan uticaj na imunsku odbranu. Međutim, oni nemaju dugotrajan uticaj na razvoj ove imunodisfunkcije, jer promene njihovih koncentracija kratko traju.

Pojedini nutricienti su uključeni u funkciju imunskih ćelija $\mathrm{i}$ tako minimiziraju inflamatorna oštećenja, zahvaljujući efikasnijem imunskom odgovoru. Moguća su brojna oštećenja tkiva za vreme infekcije, kao posledica oksidativnog stresa - reakcije nestabilnih oksidisanih molekula sa tkivnim lipidima, proteinima i DNA. Brojni antioksidansi su važni za zdravlje životinja, međutim optimalne koncentracije $\mathrm{i}$ forme ovih suplemenata za maksimiziranje imunske funkcije i zaštite tkiva, su još uvek nepoznate.

\section{References}

ANTANAITIS R., ŽILAITIS V, KUČINSKAS A. (2009): ك̌liuzo dislokacijos ankstyvosios diagnozes bei pooperacinio pasvekimo galimbyiu ivertinimas kompiuterine bandos valdymo programa. Veterinaria IR Zootechnika (Vet Med Zot), T 45(67), 3-7.

BELLA M.J., ROBERTS D.J. (2007): The impact of uterine infection on a dairy cows performance. Theriogenology, 68(7), 1074-1079.

CALDER P.C. (2008): The relationship between the fatty acid composition of immune cells and their function. Prostaglandins, Leukotrienes and Essential Fatty Acids, 79, 101-108.

CASTILlO C., HERNANDEZ J., VALVERDE I., PEREIRA V., SOTILlO J., ALONSO M.L., BENEDITO J.L. (2006): Plasma malonaldehyde (MDA) and total antioxidant status (TAS) during lactation in dairy cows. Research in Veterinary Science, 80, 133-139.

CURTIS C.R., ERB H.N., SNIFFEN C.J., SMITH R.D., KRONFELD D.S. (1985): Path analysis of dry period nutrition, postpartum metabolic and reproductive disoders, and mastitis in Holstein cows. J. Dairy Sci., 68, 2347-2360.

EL-ATTAR H.M., YASSEIN M., ABD EL-RAOF, GHANEM M.M. (2007): Alterations in the clinical, hematological and biochemical pictures in abomasal displacement in cows in Egypt. Vet.Med. J., 16, 102-109.

GITTO E., REITER R.J., KARBOWNIK M., TAN D.X., GITTO P., BARBERI S., BARBERI I. (2002): Causes of oxidative stress in the pre- and perinatal period. Biol. NeonatE, 81, 46-57. 
GUNAY A., GUNAY U., ORMAN A. (2011): Effects of retained placenta on the fertility in treated dairy cows. Bulgarian Journal of Agricultural Science, 17(1), 126-131.

HALLIWELL B., GUTTERIDEGE J.M.C. (2007): Free radicals in biology and medicine. 4th Ed.Oxford University Press. Grune Strottan, New York.

HAN Y.K., KIM I.H. (2005): Risk factors for retained placenta and the effect of retained placenta on the occurrence of postpartum diseases and subsequent reproductive performance in dairy cows. J. Vet. Sci., 6, 53-59.

JOKIĆ Ž., JOKSIMOVIĆ TODOROVIĆ M., DAVIDOVIĆ V. (2005): Organski selen u ishrani pilića u tovu. Biotehnologija u stočarstvu, 21(1-2), 79-89.

JOKSIMOVIĆ TODOROVIĆ M., JOKIĆ Ž. (2005): Uticaj visokih nivoa neorganskog selena na aktivnost glutation peroksidaze (GSH-Px) u krvnoj plazmi brojlera. Biotehnologija u stočarstvu, 21 (3-4), 125-131.

JOKSIMOVIĆ TODOROVIĆ M., JOKIĆ Ž., SINOVEC Z. Uticaj visokih nivoa organskog selena na aktivnost glutation peroksidaze (GSH-Px) u krvnoj plazmi brojlera. Veterinarski glasnik 2005; 59(3-4): 383-390.

JOKSIMOVIĆ TODOROVIĆ M., JOKIĆ Ž., HRISTOV S. (2006): The effect of different levels of organic selenium on body mass, bodyweight gain, feed conversion and selenium concentration in some gilts tissues. Acta Veterinaria, 56(5-6): 489-495.

JOKSIMOVIĆ TODOROVIĆ M., DAVIDOVIĆ V. (2007): Selenium, oxidative stress. Proceeding of Third Symposium of Livestock Production with International Participation, Ohrid, Macedonia, 12-14. September 2007: 527-530.

KIMURA K., REINHARDT T.A., GOFF J.P. (2006): Parturition and hypocalcemia blunts calcium signals in immune cells of dairy cattle. J. Dairy Sci., 89: 2588-2595.

MARTINS DE LIMA T., GORJO R., HATANAKA E., CURY-BOAVENTURA M.F., PORTIOLISILVA E.P., PROCOPIO J., CURI R. (2007): Mechanisms by which fatty acids regulate leucocyte function. Clinical Science, 113, 65-77.

MIHAILOVIĆ M., TODOROVIĆ M., ILIĆ V. (1991): Effects of dietary selenium of glutatione peroxidase activity and body weight of growing turkeys. Acta Veterinaria, 23, 75-80.

MIHAILOVIĆ M., TODOROVIĆ M., JOVANOVIĆ M., PALIĆ T., JOVANOVIĆ J., PEŠUT O., KOSANOVIĆ M. (1996a): Toxicity of organic and inorganic selenium to chicken. Ninth Intrnat. Symp. of Trace Elements in Man and Animals (Tema 9) - Banff Alberta - Canada 1996. Trace Elements in Man and Animals, 9, 554-555.

MIHAILOVIĆ M., TODOROVIĆ M., JOVANOVIĆ M., PALIĆ T., JOVANOVIĆ J., PEŠUT O., KOSANOVIĆ M. (1996b): Toxicity of sodium selenite and selenized yeast to chicken. The Sixt Intrnat. Symp. on selenium in Biol. and Med. - Peking NR Kina 1996. Program and Abstract, 125. 
MIHAILOVIĆ M., TODOROVIĆ M., JOVANOVIĆ M., PALIĆ T., JOVANOVIĆ J., PEŠUT O. (1997): Toxicity of selenium to broilers. XI ${ }^{\text {th }}$ International Congres of the World Poultry Association 18-22 August, Budapest, Hungary.

MOKHBER DEZFOULI M., EFTEKHARI Z., SADEGHIAN S., BAHOUNAR A., JELOUDARI M. (2011): Evaluation of hematological and biochemical profiles in dairy cows with left displacement of the abomasum. Comp. Clin. Pathol., DOI 10.1007/s00580-011-1382-5.

NONNECKE B.J., FRANKLIN S.T., YOUNG J.V. (1992): Effects of ketones, acetate, and glucose on in vitro immunoglobulin secretion by bovine lymphocytes. J. Dairy Sci., 75: 982-990.

PERKINS K.H., VANDEHAAR M.J., TEMPELMAN R.J., BURTON J.L. (2001): Negative energy balance does not decrease expression of leukocyte adhesion or antigen-presenting molecules in cattle. J. Dairy Sci., 84: 421-428.

SHARMA N., SINGH N.K., SINGH O.P., PANDEY V., VERMA P.K. (2011): Oxidative Stress and Antioxidant Status during Transition Period in Dairy Cows. Asian-Aust. J. Anim. Sci., 24(4): 479-484.

SORDILLO L.M., STREICHER K.L. (2002): Mammary gland immunity and mastitis susceptibility. J Mammary Gland Biol. Neoplasia, 7: 135-146.

SORDILLO L.M. (2005): Factors affecting mammary gland immunity mastitis susceptibility. Livestok Prod. Sci., 98: 89-99.

SORDILLO L.M., AITKEN S.L. (2009): Impact of oxidative stress on the health and immune function of dairy cattle. Vet. Immunol. Immunopathol., 128: 104-109. SORDILLO L.M., CONTRERAS G.A., AITKEN S.L. (2009): Metabolic factors affecting the imflammatory response of periparturient dairy cows. Animal Health Research Reviews, 10(1): 53-63.

SORDILLO L.M. (2011): New Concepts in the Causes and Control of Mastitis. Mammary Gland Biol. Neoplasia, 16: 271-273.

SPEARS J.W., WEISS W.P. (2008): Role of antioxidants and trace elements in health and immunity of transition dairy cows. Vet. J., 176: 70-76.

SURIYASATHAPORN W., HEUER C., NOORDHUIZE-STASSEN E.N., SCHUKKEN Y.H. (2000): Hyperketonemija and the impairment of udder defense: a review. Vet. Res., 31: 397-412.

TODOROVIĆ M., MIHAILOVIĆ M., HRISTOV S. (1999): Effects of excessive levels of sodium selenite on daily weight gain, mortality and plasma selenium concentration in chickens. Acta Veterinaria, 49(5-6): 313-320.

TREVISAN M., BROWNE R., RAM M., MUTI P., FREUDENHEIM J., CAROSELLA A.N., ARMSTRONG D. (2001): Correlates of markers of oxidative status in the general population. Am. J. Epidemiol., 154: 348-356.

VALKO M., LEIBFRITZ D., MONCOL J., CRONIN M.T., MAZUR M., TELSER J. (2007): Free radicals and antioxidants in normal physiological 
functions and human disease. International Journal of Biochemistry and Cell Biology, 39: 44-84.

ZADNIK T. (2003): Review of anterior displacement of the abomasum in cattle in Slovenia. Veterinary Record, 153(1): 24-25.

WALDRON M.R., REVELO X.S. (2008): Causes and Effects of Periparturient Immunosuppression. WCDS Advances in Dairy Tehnology, 20: 97-109.

WALDRON M.R.(2010): Impact of Metabolic and Oxidative Stressors on Periparturient Immune Fuction and Health. Penn State Dairy Cattle Nutrition Workshop, 33-9.

WEBER P.S., MADSEN S.A., SMITH G.W., IRELAND J.J., BURTON J.L. (2001): Pre-translational egulation of neutrophil L-selection in glucocorticoidchallenged cattle. Vet. Immunol. Immunopathol., 83: 213-240.

WILDE D. (2006): Influence of macro and micro minerals in the periparturient period on fertility in dairy cattle. Anim. Peprod. Sci., 96: 240-249.

WOOD L.G., SCOTT H.A., GARG M.L., GIBSON P.G. (2009): Innate immune mechanisms linking non-esterified fatty acids and respiratory disease. Progress in Lipid Research., 48: 27-43.

Received 9 April 2013; accepted for publication 10 June 2013 